\title{
海域底質中のポリ塩化ビフェニルのコンジェナー別分析 一前処理法に関する考察—
}

\author{
姉崎 克典 \\ 北海道立総合研究機構 環境・地質研究本部 環境科学研究センター \\ （ ₹060-0819＼cjkstart北海道札幌市北区北19条西12丁目）
}

[平成23年 4 月 20 日受付, 平成23年 7 月 12 日受理］

\section{Determination of All PCB Congeners in Marine Sediment -Comparison Study of Pretreatment Methods-}

\author{
Katsunori ANEZAKI \\ Hokkaido Research Organization, Environmental and Geological Research Department, \\ Institute of Environmental Sciences \\ (N19W12, Kita, Sapporo, Hokkaido 060-0819)
}

[Received April 20, 2011; Accepted July 12, 2011]

\begin{abstract}
Summary
The author compared the six pretreatment methods for the analysis of PCBs in marine sediment, including the warming alkaline treatment method. The results of the six pretreatment methods showed nearly equal total PCBs concentration, but the analysis for each homologue and each congener indicated that in the case of the warming alkaline treatment method, high chlorinated congeners decreased and the amount of low chlorinated congeners was significantly low compared with the other methods. The other pretreatment methods showed almost the same results for each homologue and each congener, and surrogate recoveries were good. In addition, it was found that the pressurized liquid extraction with toluene-room temperature alkaline treatment method and the Discovery ${ }^{\circledR} \mathrm{Ag}$-ION SPE tube-based treatment are effective for removing impurities, such as mineral oil, in the pretreatment.
\end{abstract}

Key words: PCBs, marine sediment, pretreatment, alkaline treatment

\section{1. はじめに}

ポリ塩化ビフェニル (PCBs) は, その物理的・化学的安定性か ら様々な用途に広く使用され, それに伴い大気, 水, 土壤といった 環境中へ放出され, 気温等の気象要因により大気一海・土壤間の移 行を繰り返して地球全体に拡散し, 水圈の底質や生物等に蓄積され てきた。そのため, PCBsの製造・使用が中止されて 30 年以上経 た現在でも, 一般的な環境を含む様々な媒体から PCBs が検出され ている ${ }^{1)}$ 。特に海域における底質は拡散が起こりにくいことから， 閉鎖性の海域で高濃度に蓄積されていることが報告されている1）。

底質中の PCBs の測定には長年にわたり加温アルカリ分解－溶媒 抽出一電子捕獲検出器による方法がほぼ公定法的に用いられてき た2)。この方法は特に油分を主体とした多くの夾雑物を含む底質を 効果的に分解処理できる反面, 操作の煩雑さや分解途中において目 的物である PCBs まで分解されるという久点が指摘されている3 また, 近年では PCBs の組成の把握 ${ }^{4,5)}$ や污染由来の解明 6,7$)$, 生物 濃縮の解明8) 等のために測定をコンジェナー別に精確に行う必要性
が認識され，より詳細なデータが期待できる高分解能ガスクロマト グラフ質量分析計（HRGC/HRMS）による報告も増えつつある。

これらのことから, 多くの研究者によってアルカリ分解法の代替 となる前処理法が提案されており, 例えば底質からの抽出をソック スレー抽出法や高圧流体抽出 (pressurized liquid extraction, PLE) 法1,9-11)により行い, その抽出液を室温でアルカリ分解処理する方 法9)や, ジメチルスルホキシド（DMSO）分配により夾雑物を除去 する方法12) が検討されてきた。また，近年では煩雑で熟練を要す るDMSO 分配処理と同等の前処理をオープンカラムで行う方法 ${ }^{13)}$ や, 特に芳香族炭化水素の除去を目的として銀イオンを結合させ たシリカゲルカラムを用いる方法 ${ }^{14)}$ が開発され, 絶縁油中の PCBs 分析へ適用されるなど新たな前処理法も提案されている。しかしな がら, これらの前処理法について全 PCB コンジェナーの組成解析 を行うという目的としての妥当性を検討した報告は少ない。

このことを踏まえ, 本報では従来法である加温アルカリ分解法と 種々の前処理法を比較検討し, それぞれの方法における PCBs 定量 值やクリーンアップ効果などについて考察したので報告する。 


\section{2. 方法}

\section{1 試薬及び試料}

\section{1.1 試薬}

PCBs の標準物質は Wellington製または Cambridge Isotope Laboratories 製のものを希鄱調整して使用した。使用したコンジェ ナーを Table 1 に示す。なお，本報では各 PCBs コンジェナーの名 称は，全て IUPAC numberで表記した。水酸化カリウムは関東化 学製の残留農薬試験用を使用した。DMSO 及び濃硫酸は和光純薬 工業製のインフィニティピュア及び精密分析用をそれぞれ使用し た。還元銅はキシダ化学製の有機元素分析用（線状）を使用前にへ キサンで超音波洗浄して使用した。Supelclean ${ }^{\mathrm{T} M}$ スルホキシド SPE チューブ（6g/20 mL）（スルホキシドカラム）及び Discovery ${ }^{\mathbb{B}} \mathrm{Ag}$ ION SPE チューブ（750 mg/6 mL）（Ag-ION カラム）はスペルコ 製のものを使用した。その他の試薬は全て和光純薬工業製のダイオ キシン類分析用を使用した。

\section{1.2 試料}

海域底質試料として平成 22 年度環境測定分析統一精度管理調査 における底質試料を使用した ${ }^{15)}$

\section{2 装置}

PLE はダイオネクス製 ASE-300を使用した。高速液体クロマ トグラフ（HPLC）は，島津製作所製 LC-10ATvpを使用した。 HRGC/HRMS は，Agilent 製 6890 及び日本電子製 JMS-700D を
それぞれ使用し、キャピラリーカラムには HT8-PCB（関東化学 $60 \mathrm{~m} \cdot 0.25 \mathrm{~mm}$ i.d. $)^{16)}$ を使用した。

\section{3 前処理方法}

本検討では以下の 6 法の前処理法について検討した。概略を Table 2 に示す。

\section{3. 1 加温アルカリ分解一溶媒抽出（Method A)}

底質調查方法 ${ }^{2)}$ に準拠したが，以下のとおりシリカゲルカラムク ロマトグラフィーを多層シリカゲルカラムクロマトグラフィーに変 更して実施した。

底質試料の数百 $\mathrm{mg}$ を正確にはかり取り, $200 \mathrm{~mL}$ のなす形フラ スコに移した。これに $1 \mathrm{~mol} / \mathrm{L}$ 水酸化カリウムのエタノール溶液 $50 \mathrm{~mL}$ とサロゲートを 1 〜 ng 添加し, 還流冷却管に装着して途 中で数回なす形フラスコを摚找しながら $80{ }^{\circ} \mathrm{C}$ の湯浴において 1 時 間アルカリ分解を行った。分解後, 還流冷却管を $50 \mathrm{~mL}$ のへキサ ンで洗い流し, 分解液と合わせた。これを孔径 $1 \mu \mathrm{m}$ のガラス繊維 ろ紙でろ過し，万過残渣をエタノール／ヘキサン（1：1） $20 \mathrm{~mL}$ 及 びへキサン $30 \mathrm{~mL}$ で洗浄した。得られたろ液を $300 \mathrm{~mL}$ の分液漏斗 に移し, 超純水 $50 \mathrm{~mL}$ を加え 10 分間振とうした。十分に分離後, 水相を $200 \mathrm{~mL}$ の分液漏斗に移し，ヘキサン $50 \mathrm{~mL}$ を加え再度 10 分間振とうした。得られたへキサン相を先の $300 \mathrm{~mL}$ 分液漏斗に移 し合わせ，濃硫酸を $20 〜 30 \mathrm{~mL}$ 添加して振とうした。これを硫酸 相の着色が薄くなるまで数回繰り返した。へキサン相を $100 \mathrm{~mL} の$ 超純水で 3 回洗浄し, 硫酸ナトリウムで脱水した。得られたへキサ

Table 1 List of PCB standards

\begin{tabular}{llll}
\hline homologue & Native & Surrogate $^{1)}$ & $\begin{array}{l}\text { Recovery } \\
\text { standard }^{1)}\end{array}$ \\
\hline MonoCBs & $\# 1, \# 3$ & $\# 3$ & $\# 9$ \\
DiCBs & $\# 8, \# 9, \# 10, \# 12, \# 15$ & $\# 15$ & $\# 32$ \\
TriCBs & $\# 18, \# 19, \# 33, \# 35, \# 37, \# 38$ & $\# 28$ & $\# 70$ \\
TetraCBs & $\# 44, \# 52, \# 54, \# 57, \# 74, \# 77, \# 78, \# 79, \# 81$ & $\# 60$ & $\# 97$ \\
PentaCBs & $\# 99, \# 104, \# 114, \# 118, \# 123, \# 126$ & $\# 101$ & $\# 153$ \\
HexaCBs & $\# 153, \# 155, \# 156, \# 157, \# 162, \# 167, \# 169$ & $\# 141$ & $\# 180$ \\
HeptaCBs & $\# 188, \# 189$ & $\# 178$ & $\# 194$ \\
OctaCBs & $\# 194, \# 195, \# 202, \# 205$ & $\# 208$ & $\# 205$ \\
NonaCBs & $\# 206, \# 208$ & $\# 209$ & $\# 206$ \\
DecaCB & $\# 209$ & &
\end{tabular}

1) denote ${ }^{13} \mathrm{C}_{12}$ labeled standards

Table 2 List of pretreatment procedures in this study

\begin{tabular}{|c|c|c|c|c|c|c|}
\hline & \multicolumn{6}{|c|}{ Method } \\
\hline & $\mathrm{A}$ & $\mathrm{B}$ & $\mathrm{C}$ & $\mathrm{D}$ & $\mathrm{E}$ & $\mathrm{F}$ \\
\hline \multicolumn{7}{|l|}{ Treatment } \\
\hline Alkaline treatment at $80^{\circ} \mathrm{C}$ & $\circ$ & & & & & \\
\hline PLE with toluene & & $\circ$ & $\circ$ & $\circ$ & $\circ$ & $\circ$ \\
\hline Alkaline treatment at room temp. & & $\circ$ & & & & \\
\hline $\mathrm{H}_{2} \mathrm{SO}_{4}$ & $\circ$ & $\circ$ & $\circ$ & $\circ$ & $\circ$ & $\circ$ \\
\hline DMSO partitioning treatment & & & & $\circ$ & & \\
\hline $\begin{array}{l}\text { Multi layer column chromatography } \\
\text { except for } \mathrm{AgNO}_{3} \text { silica gel }\end{array}$ & $\circ$ & $\circ$ & $\circ$ & $\circ$ & $\circ$ & $\circ$ \\
\hline Reduced copper & $\circ$ & $\circ$ & $\circ$ & $\circ$ & $\circ$ & $\circ$ \\
\hline HPLC & & & $\circ$ & & & \\
\hline Sulfoxide SPE & & & & & $\circ$ & $\circ$ \\
\hline Ag-ION SPE & & & & & & $\circ$ \\
\hline
\end{tabular}


ン相を $1 \mathrm{~mL}$ 程度まで減圧濃縮したあと， $200 \mathrm{~mL}$ のヘキサンによ り多層シリカゲルカラムクロマトグラフィー12,17) で処理した。な お，この多層シリカゲルカラムクロマトグラフィーでは，低塩素化 PCBs の回収が妨げられることから 10 \% 硝酸銀シリカゲルは適用 しなかった ${ }^{18)}$ 。次に還元銅を試料液に $10 \sim 20 \mathrm{~g}$ 程度加えよく擋拌 し, 約 3 時間程度静置した。還元銅を取り除き，濃縮して回収率算 定用の内標準物質を添加し, 緩やかな窒素気流にて $50 \mu \mathrm{L}$ 程度の) ナン溶液とした。

\section{3. 2 PLE-室温アルカリ分解9) (Method B)}

底質試料の数百 $\mathrm{mg}$ を正確にはかり取り, PLE（溶媒：トルエン， 温度： $150{ }^{\circ} \mathrm{C}$, 圧力 $1,500 \mathrm{psi}$, 静置時間 15 分, フラッシュ $150 \%$, サイクル 2 回）で抽出処理した。抽出液にサロゲート $1 \sim 5 \mathrm{ng}$ 添 加してトルエンを除去後, $1 \mathrm{~mol} / \mathrm{L}$ 水酸化カリウムのエ夕ノール溶 液 $25 \mathrm{~mL}$ 添加し暗所に室温 $\left(20{ }^{\circ} \mathrm{C}\right)$ で 1 時間静置した。これを孔 径 $1 \mu \mathrm{m}$ のガラス繊維ろ紙で濾過し， ろ過残渣をエタノール/へキ サン（1：1）の $20 \mathrm{~mL}$ 及びヘキサン $30 \mathrm{~mL}$ で洗浄した。得られた 万液を $300 \mathrm{~mL}$ の分液漏斗に移し, $50 \mathrm{~mL}$ 超純水を加え 10 分間振 とうした。十分に分離後, 水相を $200 \mathrm{~mL}$ の分液漏斗に移し、へキ サン $50 \mathrm{~mL}$ を加え再度 10 分間振とうした。以下, 2.3 .1 と同様に 硫酸処理，多層シリカゲルカラムクロマトグラフ処理，還元銅処理 を行い, 濃縮して回収率算定用の内標準物質を添加し, $50 \mu \mathrm{L}$ 程度 のノナン溶液とした。

\section{3. 3 PLE-HPLC 処理 (Method C)}

2. 3.2 と同様にPLE で抽出しサロゲートを添加して 2.3.1 と同 様に硫酸処理, 多層シリカゲルカラムクロマトグラフ処理, 還元 銅処理を行った。試料液を濃縮後 HPLC ${ }^{12}$ （カラム：SHANDON Hypercarb S $100 \mathrm{~mm} \times 4.6 \mathrm{~mm}$ i.d.) で処理し, PCBのフラクショ ンを濃縮して回収率算定用の内標準物質を添加し, $50 \mu \mathrm{L}$ 程度のノ ナン溶液とした。

\section{3. 4 PLE-DMSO 処理 ${ }^{12)}$ (Method D)}

2.3.2 と同様にPLEで抽出しサロゲートを添加して 2.3.1 と同 様に硫酸処理した。試料液を $10 \mathrm{~mL}$ のヘキサン溶液とし, DMSO を $25 \mathrm{~mL}$ 加え 20 分間振とうした。これを 4 回繰り返し, 各 DMSO 相を合わせ超純水 $100 \mathrm{~mL}$ を加えて均一化した後, ヘキサン $70 \mathrm{~mL}$ を加え 20 分間振とうした。これを 4 回繰り返し, 各へキサン相を 合わせ, 超純水 $200 \mathrm{~mL}$ で水洗し, 硫酸ナトリウムで脱水した。以 下，2.3.1 と同様に多層シリカゲルカラムクロマトグラフ処理, 還 元銅処理を行い, 濃縮して回収率算定用の内標準物質を添加し, $50 \mu \mathrm{L}$ 程度のノナン溶液とした。

\section{3. 5 PLE-スルホキシドカラム処理 (Method E)}

2. 3.2 と同様にPLE で抽出しサロゲートを添加して 2.3.1 と同 様に硫酸処理, 多層シリカゲルカラムクロマトグラフ処理, 還元 銅処理を行った。スルホキシドカラムをアセトン及びヘキサンそ れぞれ $20 \mathrm{~mL}$ でコンディショニングし, $1 \mathrm{~mL}$ 程度に濃縮した試料 液を添加し, ヘキサン $9 \mathrm{~mL}$ で夾雑物を溶出させ, 次いでへキサン $60 \mathrm{~mL}$ で PCBs を溶出させた ${ }^{13)}$ 。このフラクションを濃縮して回収 率算定用の内標準物質を添加し，50 $\mu \mathrm{L}$ 程度のノナン溶液とした。

\section{3. 6 PLE-スルホキシドカラム-Ag-ION カラム処理 (Method F)}

2. 3.2 と同様にPLEで抽出しサロゲートを添加して 2.3.1 と同 様に硫酸処理, 多層シリカゲルカラムクロマトグラフ処理, 還元 銅処理を行った。スルホキシドカラムを 2.3.5 と同様にコンディ ショニングした後, $1 \mathrm{~mL}$ 程度に濃縮した試料液を添加し，まずへ キサン $9 \mathrm{~mL}$ で夾雑物を溶出させた。次にアセトン $10 \mathrm{~mL}$ 及びへキ サン $20 \mathrm{~mL}$ でコンディショニングした Ag-ION カラムをスルホキシ ドカラムの下部に連結し， $5 \%$ \%ジロロメタン/ヘキサン $50 \mathrm{~mL} て ゙$
PCBs を溶出させた ${ }^{14,19)}$ 。このフラクションを濃縮して回収率算定 用の内標準物質を添加し， $50 \mu \mathrm{L}$ 程度のノナン溶液とした。

\section{3. 結果と考察}

\section{1 PLE による PCB の抽出}

底質の PCBs の抽出には加温アルカリ分解一溶媒抽出のほか, 卜 ルエンソックスレー抽出による方法も適用されている。しかしな がら，ソックスレー抽出は概ね 16 時間以上行うことが求められる ことから, 簡便性や安全性の観点から PLE も適用されつつあり, ソックスレー抽出と同等以上の抽出効率を持つことが確認されてい る ${ }^{10,11,20,21)}$ 。本検討で用いた海域底質試料についても, PLEで抽出 後に再度同条件で抽出を行い，その抽出液について PCBs を定量し たところ, 操作ブランクと同程度であり最初の抽出操作で定量的に 抽出されていることが確認された。そこで抽出をPLEで行う場合, サロゲートはその抽出液に添加することとした。

\section{2 各処理法による PCBs 測定結果}

Table 3 に各前処理法による PCBs の定量結果及びサロゲートの 回収率を示す。それぞれの全 PCBs 濃度は $157 \sim 175 \mathrm{ng} / \mathrm{g}$ であり， 概ね一致しているものと認められた。また, この值は環境測定分析 統一精度管理調査に扔ける本底質のキャピラリーカラムーガスクロ マトグラフ高分解能質量分析計による諸分析機関の測定結果の平均 值（159 ng/g）ともほぼ一致していた22)。

同族体別及びコンジェナー別の濃度は加温アルカリ分解 (Method A）では十塩素化物のサロゲート回収率が数\%程度であり, 定量 が不能であった上，一〜三塩素化物では他の前処理法に比べ $10 〜$ $60 \%$ 程度低い值となり, 特に一塩素化物について顕著であった。 十塩素化物以外のサロゲートの回収率については九塩素化物で $25 \%$ 程度であり, 極めて低い回収率となった。加温アルカリ分解 による PCB 分析においては処理中に高塩素化物が分解する可能性 が指摘されており ${ }^{3)}$, 本検討に扔いても同様の結果となった。一方, 二及び三塩素化物の回収率はそれぞれ $113,114 \%$ であり，他の前 処理法のサロゲートと比較して高い回収率であった。

加温アルカリ分解以外の 5 法 $($ Method B $\sim \mathrm{F})$ については, 一 塩素化物でやや結果にばらつきがあるが, その他の同族体別濃度 及びコンジェナー別濃度のいずれも概ね同等の定量值を得た。ま た, 各同族体濃度は上記統一精度管理調査の結果 (MoCBs: 1. 12, DiCBs: 3. 66, TrCBs: 15. 2, TeCBs: 36. 7, PeCBs: 44. 1, HxCBs: 36. 1, HpCBs: 12. 5, OcCBs: 2. 86, NoCBs: 0. 346, DeCB: 0.359, 単位:ng/g) とも概ね一致していた。サロゲートの回収率についても一塩素化物 を除き各法とも概ね 70 〜 105 \%であり良好な結果を得た。一塩素 化物では各法とも $46 \sim 73 \%$ にとどまっていたが, これは前処理中 の濃縮の際に揮発したものと推測された。

\section{3 加温アルカリ分解による PCBs コンジェナーの変化}

加温アルカリ分解により一部のコンジェナーが大幅に減少した り, 一部のサロゲートの回収率が高くなる等の影響が認められたこ とから, Native 体のスタンダードを用いて加温アルカリ分解によ る PCBs コンジェナーの組成の変化について検討した。Table 1 に 示す 44 種の Native 体コンジェナー 2 $4 \mathrm{ng}$ を加温アルカリ分解 した後, 得られた処理液にサロゲートを添加して多層シリカゲルカ ラムクロマトグラフィーで処理を行った。得られた溶離液に回収 率算定用の内標準物質を添加後, 濃縮して HRGC/HRMS で測定し た。結果を Fig. 1 に示す。回収率は十塩素化物（\#209）では数\%程 度と非常に低く, 九塩素化物（\#206, \#208）は30\%程度, 八塩素 


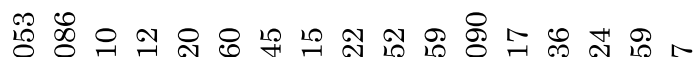

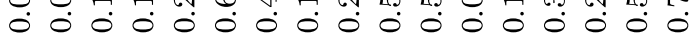
H H H H H H H H H H H H H H H H H

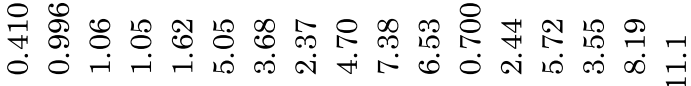

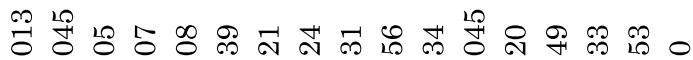

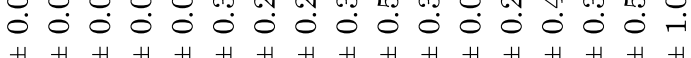

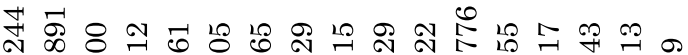

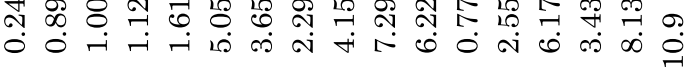

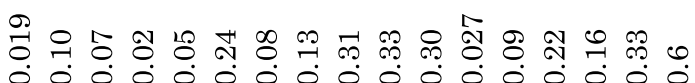

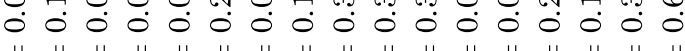

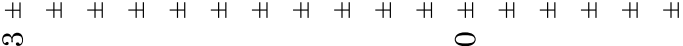
旁

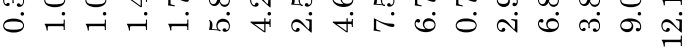

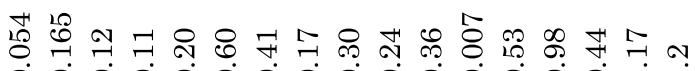

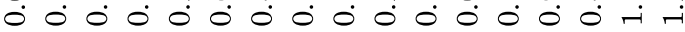
H H H H H H H H H H H H H H H H H

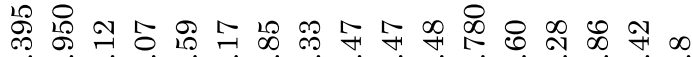

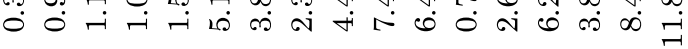

ปิ

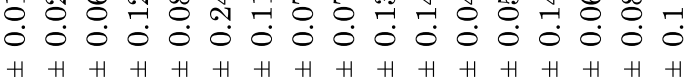
๙ ช.

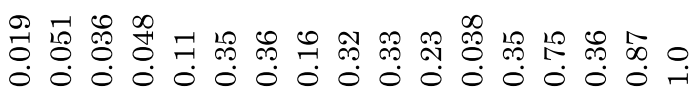
H H H H H H H H H H H H H H H

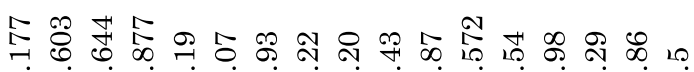
0000 - 


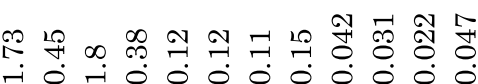

$\mathrm{H} H+\mathrm{H} H+\mathrm{H} H+\mathrm{H} H$

$\begin{array}{llll}0 & \text { H } & 0\end{array}$

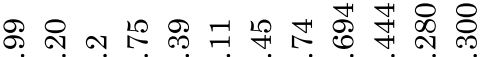

$\mathrm{H} H \mathrm{H} H \mathrm{H} H \mathrm{H} H \mathrm{H}$

மㄷ요요 \&

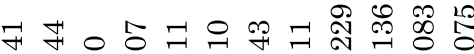

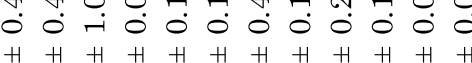
북 님

$\begin{array}{llllllllll}H & \cdots & \infty & \cdots & \infty & \infty & H & 0 & \infty & H \\ H & H & H & H & H & H & H & H & H & H\end{array}$

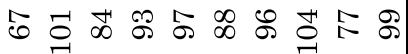

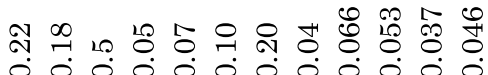
H H H H H H H H H H H H

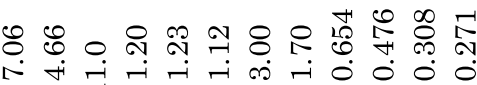

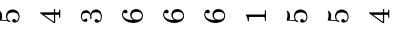

$\mathrm{H}+\mathrm{H}+\mathrm{H} H \mathrm{H} H \mathrm{H}$

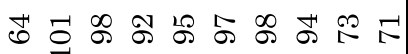

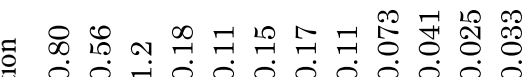
๓ ำ ำ

$\mathrm{H}+\mathrm{H}+\mathrm{H}+\mathrm{H}+\mathrm{H}+\mathrm{H}$

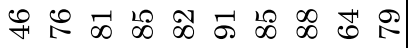
常

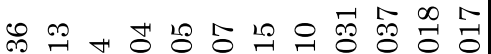

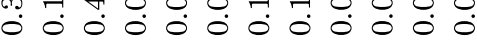
H H H H H H H H H H H H

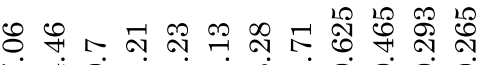

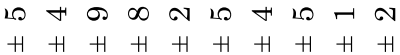

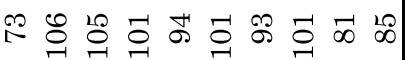

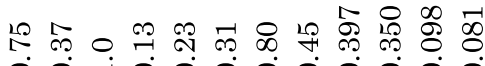

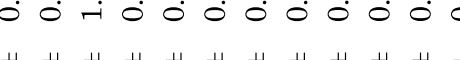
ఫ্ট

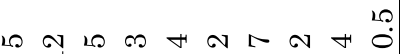
$\mathrm{H}+\mathrm{H} H \mathrm{H} H \mathrm{H}+\mathrm{H} H$ ז

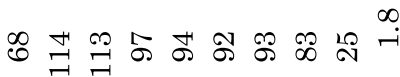

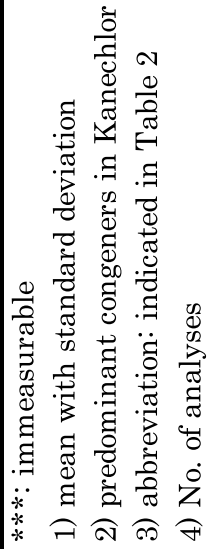




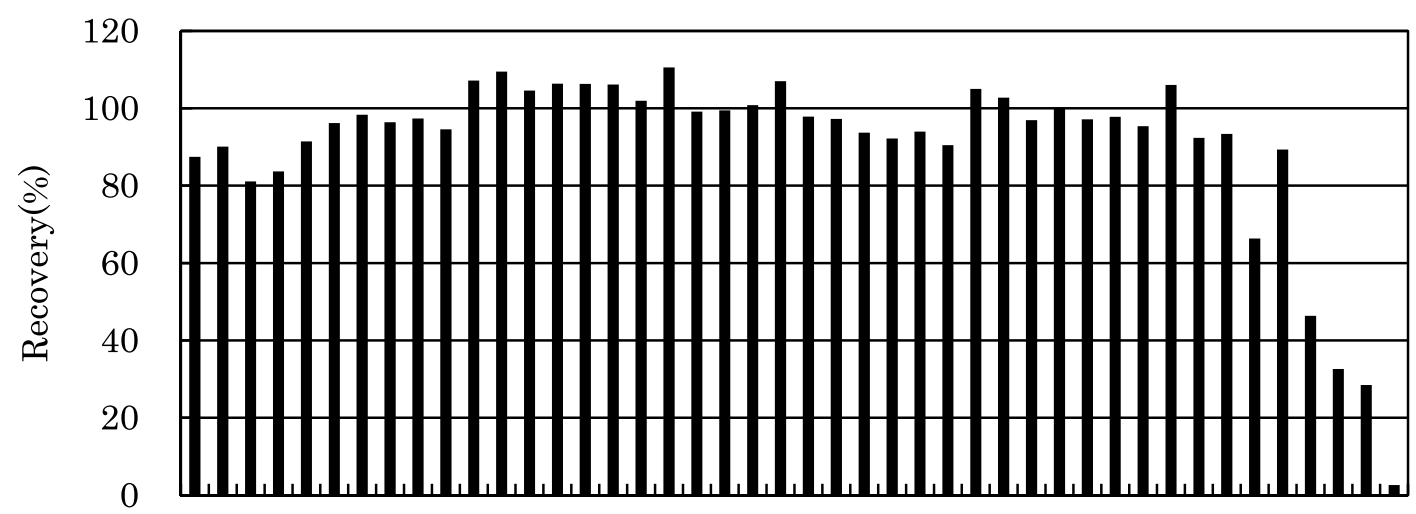

\#mo

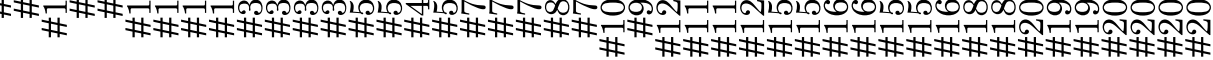

Fig. 1 Effect of alkaline treatment at $80{ }^{\circ} \mathrm{C}$ on PCBs recovery

化物の \#195 は 65 \%程度であり, 加温アルカリ分解により減少して いることが認められた。一塩素化物（\#1，\#3）及び二塩素化物の一 部のコンジェナー（\#9，\#10）についても $80 ９ 0$ \%程度の回収率で あり，10\%程度のロスが認められたが，加温アルカリによる分解 か，処理工程に抢ける揮発によるものかは明確ではなかった。その 他のコンジェナーについては 90 ～110％で定量的に回収されてい た。また, 検討した 44 種以外に検出されたコンジェナーはなく, 例えば高塩素化物が脱塩素してより低位の塩素化物が生成されると いった事象は認められなかった。特に予め添加されていた\#15がほ ほ 100 \%の回収率であったこと，そして添加されていない \#28につ いては生成が全く認められなかったことから，3.2において認めら れた加温アルカリ分解に拉けるこれらのコンジェナーのサロゲート の回収率の増加（Table 3）が，高塩素化物の分解によるものでは ないことが確認された。

\section{4 各前処理法による夾雑物の除去効果}

一般に港湾部における海域底質は，主に鉱油類などの油分系夾雑 物を含有することが多いが，HRGC/HRMS においてロックマス方 式による選択イオンモニタリング法（SIM）で測定を行う場合には, これらを前処理工程で効果的に除去しなければロックマスの落ち込 み等が生じるため良好な SIM クロマトグラムを得ることができず, 精確な定量ができなくなる。そこで HRGC/HRMS での測定におけ る各前処理法毎のロックマスの確認を行った。

各ロックマスクロマトグラム（PFK, m/z 242. 9856）を Fig. 2 に 示す。HPLC 処理（Method C）では，明確な油分対策が行われて いないこともあり 9 〜 13 分の保持時間において鉱油の影響と推測 されるロックマスの落ち込みが認められ, 特に低塩素化物の PCB の定量への影響が危惧された。一方，油分対策として実施される DMSO 分配処理 (Method D) でも HPLC 処理と同等のクロマトグ ラムであり効果は認められなかった。スルホキシドカラムによる処 理（Method E）も同様であったが, スルホキシドカラムと Ag-ION カラムを組み合わせた処理（Method F）ではロックマスクロマト グラムの大幅な改善が認められ，効果的なクリーンアップが行われ たものと評価された。

一方, 加温アルカリ分解 (Method A）ではロックマスに落ち込 み等は全く認められず良好なクロマトグラムが得られた。また, 室 温アルカリ分解 (Method B) でも Method C, D 及びEで認められ たようなロックマスの落ち込みは認められなかった。
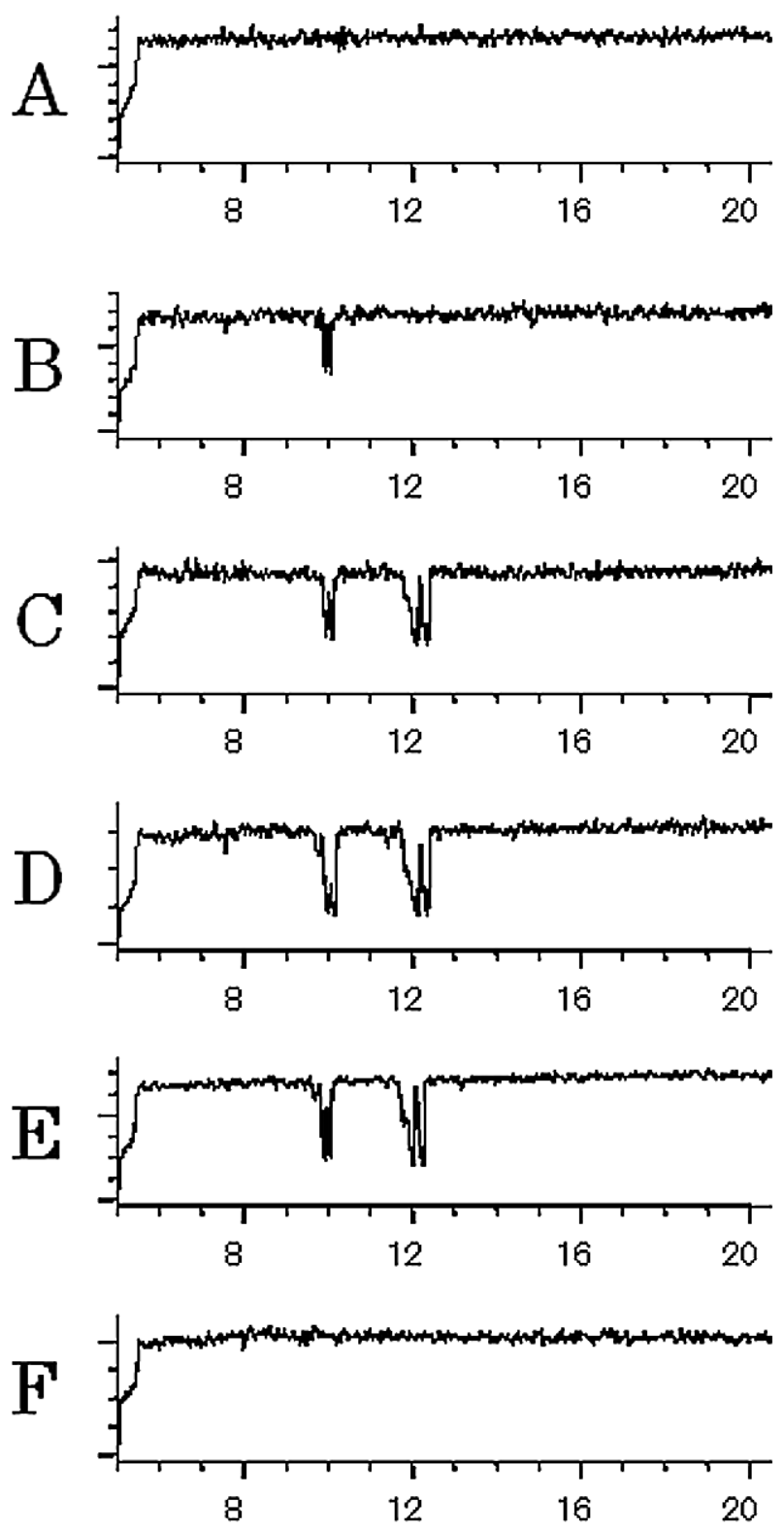

Fig. 2 Mass chromatograms of PFK(m/z 242.9856) as lock mass

Abbreviation: indicated in Table 2 


\section{4. まとめ}

加温アルカリ分解は, 夾雑物の分解除去を極めて効果的に行うこ とが可能であり，検討したクリーンアップ法の中で最も優れてい た。しかしながら，分解操作がやや煩雑であること，そして，一部 の同族体の定量值が信頼性に欠けるなどの問題点が示された。これ を解決する方法としての PLE - 室温アルカリ分解法では, 同族体 別の濃度も含め定量值は統一精度管理調査の結果とほぼ一致し，ま た，クリーンアップも効果的に行われており，有用な方法であるこ とが確認された。HPLCによる処理では，夾雑物によるものと推測 されるクロマトグラムへの影響が認められた。この処理方法は油分 対策が不十分であることから試料によってはその他のクリーンアッ プ法を組み合わせる必要があると考えられた。しかしながら，分画 条件によってはダイオキシン類と PCBs をほぼ完全に分画すること

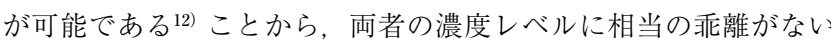
限り同時に前処理を行えるメリットは大きい。油分対策としては DMSO 分配処理が従来から行われてきており，特に生物系の油分 には極めて効果的である。しかしながら，操作が煩雑である上，本 検討のように夾雑物の種類によっては除去が困難な場合もある。こ の DMSO 分配処理の煩雑さを改良したスルホキシドカラムによる 処理は，主に絶縁油中の PCBs の処理方法として多くの成果を上げ ている。本検討においてはDMSO 分配処理と同等の結果となり, 夾雑物の除去は不完全であったが, 処理時間はカラムのコンディ ショニングを含め 1 時間程度で, 迅速かつ簡便であった。夾雑物の 種類によっては有用な処理方法であると考えられる。また，このス ルホキシドカラムに Ag-ION カラムを連結させることにより，ほぼ 加温アルカリ分解と同等の前処理効果を得ることができた。また, 定量值も PLE - 室温アルカリ分解と同等であった。

現在，底質を含む環境中の PCBs 污染はカネクロールに代表され る PCB 製品によるものであり，その主要コンジェナーは三〜八塩 素化物に集中している。よって，従来から行われている加温アルカ リ分解法よる值が不正確というものではない。また，分析の煩雑性 やコスト，さらには必ずしも全コンジェナーの精確な分析を必要と しない場合もあること等も考慮すれば，それぞれのクリーンアップ 方法に優劣は付け難い部分はある。しかしながら, PCBsの詳細分 析は全濃度の分析結果からだけでは判別できない有用な情報をもた らすことも多く，分析の目的，すなわち必要とされる情報などを考 慮し前処理法を選択することが重要であると考える。

\section{謝 辞}

検討を行うにあたり，スルホキシドカラム及び Ag-ION カラムの 分画条件等について貴重なご助言を頂いたシグマアルドリッチジャ パン株式会社の金子敏郎様及び田中和徳様に深く感謝いたします。

\section{要 約}

海域底質における PCBs 分析の前処理法として, 加温アルカリ分 解法など 6 法の比較検討を行った。全 PCBs 濃度はいずれの前処理 法でもほぼ同等の定量值が得られたが，同族体別及びコンジェナー 別では加温アルカリ分解法に扔いて，高塩素化物が分解・減少した り，低塩素化物の濃度が著しく低く算出されるなど，信頼性の低い 結果となった。その他の前処理法については同族体別，コンジェ ナー別のいずれでもほぼ一致しており，サロゲートの回収率も良好 であった。また，前処理における鉱油を主体とする夾雑物の除去に は高圧流体抽出（PLE）－室温アルカリ分解と Discovery ${ }^{\circledR}$ Ag-ION
SPEチューブによる処理がより効果的であった。

\section{文 献}

1）環境省環境保健部環境安全課：平成21年度版化学物質と環境 (2010)

2）環境省環境管理局水環境部：底質調査方法（2001）

3）高菅卓三, 青野さや香, 秋月哲也, 中川貴之, 渡邊清彦, 井上 毅：第10回環境化学討論会講演要旨集, 28-29（2001）

4) Kim, K.S., Hirai, Y., Kato, M., Urano, K. and Masunaga, S.: Detailed $\mathrm{PCB}$ congener patterns in incinerator flue gas and commercial PCB formulations(Kanechlor), Chemosphere, 55, 539-553 (2004)

5) Takasuga, T., Senthilkumar, K., Matsumura, T., Shiozaki, K. and Sakai, S.: Isotope dilution analysis of polychlorinated biphenyls (PCBs) in transformer oil and global commercial PCB formulations by high resolution gas chromatography-high resolution mass spectrometry, Chemosphere, 62, 469-484 (2006)

6) 姉崎克典, 山口勝透, 呆 庄輔, 岩田理樹, 橋本俊次: 統計学 的手法を用いるポリ塩化ビフェニルの污染由来の推定, 分析化 学, 56, 639-648 (2007)

7）本多 隆, 和田光弘, 中島憲一郎: 長崎県の大気中ポリ塩化ビ フェニルの定量とその污染特性評価, 分析化学, 58, 211-220 (2009)

8) Imaeda, D., Kunisue, T., Ochi, Y., Iwata, H., Tsydenova, O., Takahashi, S., Amano, M., Petrov, E.A., Batoev, V.B. and Tanabe, S.: Accumulation features and temporal trends of PCDDs, PCDFs and PCBs in Baikal seals(Pusa sibirica), Environ. Pollut., 157, 737-747 (2009)

9）岡本研作, 安原昭夫, 中野 武, 劒持堅志, 松村 徹, 八木孝 夫, 柿田和俊, 小野昭紘, 坂田 衞: 河川底質中ポリ塩化ビフェ ニルの分析に扔けるアルカリ分解条件等の比較検討, 分析化学, 52, 61-66 (2003)

10）鎗田 孝, 仲間純子, 沼田雅彦, 青柳嘉枝, 山崎美佐子, 高津章子: 加圧流体抽出法及び同位体希䆏 - ガスクロマトグラフィー / 質 量分析法による底質中ポリクロロビフェニルの定量, 分析化学, 52, 1011-1017 (2003)

11）姉崎克典, 山口勝透, 大塚英幸, 岩田理樹: ポリ塩化ビフェニ ル全コンジェナー分析への迅速抽出法の検討, 北海道環境科学 研究センター所報, 31，34-48（2004）

12）高菅卓三, 井上 毅, 大井悦雅：各種クリーンアップ法と HRGC/HRMS を用いたポリ塩化ビフェニル（PCBs）の全異性 体詳細分析方法, 環境化学, 5, 647-675（1995）

13）金子俊郎，Chares Mi，Michael Ye，川又 崇，沼田雅彦，大 竹貴光, 伊藤信靖, 鎗田 孝: スルホキシド基を有する固定相 を用いた絶縁油中 PCB の精製, 第16回環境化学討論会講演要 旨集，818-819（2007）

14）船越康嗣, 宮本健二, 金子俊郎：Discovery Ag-ION SPE にお ける PCB 異性体の溶出挙動, 第19回環境化学討論会講演要旨 集，408-409 (2010)

15）環境省：平成22年度環境測定分析統一精度管理調査実施要領 (2010)

16）村松千里, 鶴川正寛, 中野 武, 江崎達哉, 大橋 眞: キャピ ラリーカラム $(\mathrm{HT}$ 8-PCB) による $\mathrm{PCB}$ 全209異性体の溶出順位, 環境化学, 12, 885-865（2002）

17）日本工業規格協会 :「JIS K 0311, 排ガス中のダイオキシン類の 測定方法」, 日本規格協会, 東京 (2008) 
18）高菅卓三 : PCBs, pp417-423,「第 5 版 実験化学講座20-2 環境化学」, 日本化学会編, 丸善, 東京 (2007)

19）金子俊郎：Supelclean sulfoxide と Discovery Ag-ION を用いた 絶縁油中 PCB の簡単な前処理法, 絶縁油中 PCB の測定法セミ ナー配付資料, 東京都品川区 (11/11/2010)

20) Josefsson, S., Westbom, R., Mathiasson, L. and Björklund, E.: Evaluation of PLE exhaustiveness for the extraction of PCBs from sediments and the influence of sediment characteristics,
Anal. chim. acta, 560, 94-102 (2006)

21) Abrha, Y. and Raghavan, D.: Polychlorinated biphenyl (PCB) recovery from spiked organic matrix using accelerated solvent extraction (ASE) and Soxhlet extraction, J. Hazard. Mater., 80, 147-157 (2000)

22）環境省水 ·大気環境局総務課: 平成 22 年度環境測定分析統一精 度管理調査結果（本編）（2011） 